\title{
Paths to a Future for Youth in Protracted Refugee Situations: A View from the Thai-Burmese Border
}

\author{
Mary Purkey
}

\begin{abstract}
As youth in protracted refugee situations reach adulthood, the challenges of providing education to them have increased. Along the Thai-Burmese border, some creative approaches are being taken in order to respond to their needs. This article describes four programs, each with a different character. Although available to relatively few, they demonstrate some roles that civil society, and in particular educators and educational institutions, can play in delivering or in ensuring access to higher education for refugee youth living in protracted situations. Most critical are creativity, flexibility, and respectful collaboration between educators and both refugee and host communities.
\end{abstract}

\section{Résumé}

En matière d'éducation, les difficultés des jeunes en situation de déplacement prolongé s'accroissent au fil des années. Le long de la frontière qui sépare la Thaïlande et la Birmane, des mesures novatrices sont mises en cuvre pour répondre aux besoins de ces jeunes. Cet article décrit quatre programmes, chacun ayant un aspect particulier. Même si peu en bénéficient, ces programmes révèlent les fonctions que peut jouer la société civile, en particulier les éducateurs et les établissements d'enseignement en offrant aux jeunes réfugiés en déplacement prolongé une éducation supérieure ou en y assurant l'accès. Les éléments primordiaux sont la créativité, la souplesse et la collaboration respectueuse entre les éducateurs et la communauté des réfugiés et la communauté d'accueil.

\begin{abstract}
To gain democracy is our responsibility. So, I want to take the responsibility for my society as much as I can. To take the responsibility we need higher education ... I'm willing to help the people who are suffering many problems when I become an educated person.-Min Ma Haw student
\end{abstract}

The Thai-Burmese border is the setting for one of the numerous protracted refugee situations in the world in which a generation of displaced youth has reached young adulthood, in most cases without legal status or basic rights such as freedom of movement or the right to work or to continue education beyond a very basic level. This situation is complicated by the fact that only the 150,000 (give or take) Karen and Karenni people who live in the nine refugee camps that dot the border are considered "refugees" under Thai government policy. ${ }^{1}$ Another one to two million displaced Burmese live outside the camps working as illegal migrants, many in factories and fields surrounding the town of Mae Sot. ${ }^{2}$ With them have come enough children so that the area now hosts sixty-two informal migrant schools, some with as many as four hundred students, created over the last decade by Burmese educators eager to provide a meaningful educational experience for the displaced youth. ${ }^{3}$ As the oldest of these children reach adulthood, educational options are running out and the risk of deportation or abuse as illegal migrants looms.

This paper will describe four strategies being tried out in Mae Sot and the surrounding area in the hope of extending educational opportunity to these young adults. The common features of these programs most critical to their survival are close collaboration between educators from the international community and the displaced Burmese community, flexibility in curricula, and donor support from communities abroad. Although it is difficult to evaluate the success of programs as new as those described here, it is the thesis of this paper that the ways in which these features 
are managed will determine their success. Briefly, collaboration must be of a certain character whereby educators from the international community listen to and take their cue from their Burmese partners. Whatever their expertise in delivering education, "foreigners" who impose visions on communities such as the displaced Burmese educational community in Thailand rob these people, who have already lost so much, of their agency, their creativity, their right to define their own needs and aspirations. Burmese educators are generally eager to learn more about curriculum design and delivery but also understand their own culture and educational context in ways their partners cannot fully appreciate. Moreover, genuine partnership involves exchange and learning on both sides.

That said, on the ground, practical considerations necessarily take precedence and force Burmese educators to embrace flexibility in curriculum development and to take funding from whoever will provide it. Displaced communities have few resources and are often at the mercy of whatever skills their educational partners bring with them. For example, English and social science teachers and materials are more abundant than teachers of natural sciences. Thus whatever educational "vision" the Burmese may embrace, they usually have to take what is available. The same applies to funding which often comes with strings attached. This harsh reality makes the genuine effort to create a collaborative relationship (that at least aims to empower rather than impose) even more important, as well as more challenging.

In addition to the three common threads noted above (close collaboration between educators from the international community and the displaced Burmese community, flexibility in curricula, and donor support from communities abroad), also important to survival is the less common building of a friendly and mutually beneficial relationship between the educational partners and the host community. Unlike initiatives taken in some other protracted refugee situations in the world (e.g., Kenya), none of the programs described here is in a position to invite participation by Thai youth because either the legal status of the refugees is very precarious, they lack sufficient funding, or the political/social culture has not encouraged such developments. Despite these obstacles, two of the programs described in this paper have begun to build ties with the local Thai community, and this paper argues that efforts in this direction will contribute to long-term sustainability.

The most academically oriented of these programs is an eighteen-month diploma program in Liberal Studies offered to forty Burmese youth by the Australian Catholic University (ACU) through a combination of on-site and distance teaching. The ACU program began in 2004 with a pilot project offering a Diploma in Business. Courses were delivered online to a small group of students from Mae La Refugee Camp north of Mae Sot. After the pilot, organizers interviewed elders in the refugee community regarding their concerns, goals, and hopes for their youth, revised the program, and for logistical reasons moved it to the Mae Sot area. The current eighteen-month program, begun in 2008, includes units in Business Information Technology, English, and other courses with a social science orientation (e.g., World Geography).

Participating students are formally enrolled at ACU. Each has a student number and can access the university web pages provided for students and courses. Because ACU has limited capacity, of the eight courses in this program, four are provided by it and the remaining four by other universities. The teachers from these universities make oneyear commitments and are asked to contribute $\$ 5,000$ from their university for the infrastructure needed to support the courses they are contributing. At the time of writing, students were enrolled in four courses for six-week periods at a time (two delivered by on-site teachers and two delivered online). However, the program continues to expand and in the 2011-2012 academic year will include more and longer (twelve-week) courses. Logistical difficulties do exist. Students who have spent years in refugee camps find management of the internet communication necessary for distance education challenging, even though ACU provides an on-site tutor to assist them. In addition, for students who lack legal status, accessing the program is not simple. Finally, it is too soon to evaluate outcomes.

The second program, Min Ma Haw Educational Foundation (www.mae-sot.org), an NGO initiated four years ago by a young Australian couple in collaboration with Burmese activists in Mae Sot, prides itself on being multi-ethnic, secular, and dedicated to advancing bright students who are committed to working for their country rather than seeking resettlement. It offers two different but complementary programs. The first is a one-year program designed to prepare "post-ten" students to pass the American high school graduating equivalency test, the General Educational Development certificate (GED), in the hope that they will then be able to qualify for scholarships to universities in Thailand or elsewhere. The second involves a year of more general studies geared toward meeting the educational needs of students who have the potential to go far educationally but who are not yet ready to do the GED preparation. The curriculum of this program depends in part on available volunteer teachers. Students take courses in English, Thai, math, social studies (e.g., economics), "Burma Issues," and science when the school can find a volunteer to teach it. They learn to read relatively complex texts and to write essays. They hope to build their skills and 
knowledge so that they can qualify for the GED preparation program and/or win scholarships to university.

Min Ma Haw collaborates with the Thabyay Foundation, originally a creation of the Soros Foundation's Open Society Institute, now a registered Thai charity that matches qualified Burmese students with available scholarships funded by a number of international NGOs (e.g., Prospect Burma, a British NGO) so that they can attend Thai universities willing to accept them. ${ }^{4}$ In 2009 , thirty-six scholarships were granted to Burmese youth. A few of them were Min Ma Haw students. The school staff helps these successful students take the next steps, such as obtaining legal documents (student visas) and relocating. It also tries to help students who do not qualify. During the last months, it has begun to collaborate with Youth Connect, a vocational program described below, as well as to implement training in bookkeeping, journalism, computer skills, and "business through agriculture" to provide educational alternatives for these students.

Several challenges at Min Ma Haw are the need for longterm commitments from volunteer teachers (noted above), the difficulty of recruiting science teachers, and the lack of guaranteed funding needed to insure the continuity and integrity of the program while meeting the expanding demand. The school is supported by both Burmese and international organizations and individual donors on a month-by-month, ad hoc basis. Thus its existence is tenuous. Nonetheless, it has more than enough applicants. Last year, the school interviewed six hundred students, aged seventeen to twenty-four, for its sixty places. They come both from inside Burma and from refugee camps and migrant schools. They live, study, laugh, sing, and dream together, counting on the school to find donors and on their own belief in the promise and power of education to transform their own lives and the world.

Most youth confined to a refugee/illegal migrant existence have more modest aspirations than the Min Ma Haw or ACU students. Many Burmese youth are simply looking for employment that will enable them to avoid the slavelike conditions endured by illegal factory and field workers. During the last two years, a vocational training program started by a young American with deep ties to the local Thai and Burmese communities in Mae Sot has begun to respond to the needs of this population. It is called Youth Connect (youthconnectthailand.org). The Youth Connect Project has four components. The first is a six-month training that includes practical Thai language and preparation in "life skills" such as budgeting, nutrition and health, addiction avoidance, and communication. Six paid Burmese and Thai trainers deliver this program to 250 students at two of the migrant schools in Mae Sot. Volunteer teachers are used only if they have special skill sets and are able to stay for extended periods of time. This training program allows Youth Connect to create a database on the participating students that helps its staff determine which students will be accepted to participate in the second of its programs.

The second program is a three-month apprenticeship with a Thai business. A number of crucial elements make the apprenticeships possible. First, Youth Connect selects reputable employers and pays the student apprentices so that the employers benefit from free labour. Perhaps more important, the Youth Connect team has negotiated an informal agreement with local police and immigration authorities that enables the youth to receive a three-month apprenticeship ID card which can be extended beyond the three months if the employers wish. At this point, employers agree to pay, but the youth are technically (legally, that is) not "employed" (only apprenticed). Youth Connect takes responsibility for apprentices' good behaviour and the employers are happy. Last year sixty students participated.

Two other programs complete the Youth Connect effort to provide a holistic approach to vocational training: a career counselling centre and a social enterprises project. The career counselling centre guides and tries to place youth who have completed an apprenticeship but not received employment. In the last year, of the twenty who participated, nineteen were placed. Students who have completed an apprenticeship may also apply to participate in several Youth Connect entrepreneurship projects: a motorcycle repair shop, a woodworking (furniture making) project, and a guest house. Finally, for youth who have used up the above avenues for employment or who are waiting for employment, Youth Connect provides short term, zero per cent interest loans on the condition that the youth commit to a budget plan.

In a country where abuse of migrant workers, frequent deportations, and confinement of migrants and asylum seekers are the order of the day, Youth Connect represents a ray of light created by creative thinking, hard work, good will at a local level, and donor support (in this case provided by a Swiss organization). Its goal is to provide a continuous vocational program that will lead energetic and hardworking youth from the migrant school world to responsible adulthood. While it does not solve the problem of lack of legal status, it provides skills that could become a bridge either to genuine integration into Thai society or to the ability to contribute to the reconstruction of Burma/Myanmar should return become possible.

As one Youth Connect student, a young woman employed by a foundation for women in Mae Sot, commented: "I am so glad that I attended Youth Connect training program. 
Youth Connect provided me learning materials and taught me many essential skills that I can apply for my current job. Moreover, they assisted me with my work permit." Another, an apprentice at a Mae Sot Guest House, had this view: "I am so thankful and I am so proud to be one of students of Youth Connect because before I attended Youth Connect training program, I had thought that Thai language was not important for me ... they taught me how to speak, write, and read Thai language. Moreover, they taught me about soft skills including solving problem, customer service, and communication ... Now I am able to communicate in Thai language, and it helps me a lot with my work." Thai employers seem also content: "Youth Connect is a good organization. They provide both essential knowledge and work experience for migrant students. Youth Connect is an organization that really benefits to society ... and students who graduated from Youth Connect program really show potential" (the second in charge of human resources at the biggest of Mae Sot's hotels). As the program unfolds in the years to come, it is without doubt this carefully nurtured relationship with the Thai business community that will help to insure its success.

The final educational initiative in this survey is Kaw Tha Blay Learning Centre (KTBLC), a "college" project situated in a Thai Karen village two hours north of Mae Sot. ${ }^{5}$ It was started in 2005 through close collaboration between its Karen founder and a Canadian couple who shared a desire to foster development of civil society in Karen State in eastern Burma through higher education, then unavailable to Karen refugee youth either in Karen State or in the refugee camps on the border. They hoped that Karen youth would dedicate themselves to becoming leaders rather than resettle to Western countries. The Canadians reached out to their own community for support and created Project Umbrella Burma (PUB) (www.projectumbrellaburma.com), the small Canadian NGO that funds KTBLC.

At its inception, Kaw Tha Blay was located in Karen State as a matter of principle if not efficacy. Its founders wanted Karen youth to take pride in asserting the right to have education in their homeland. Sadly, in 2008-09 as the war encroached upon the border, the school was forced to move to its current home on land purchased from a Thai Karen patron. Ties of friendship have grown between the Thai Karen villagers and the school during the last three years. It now has a bona fide "campus" with five buildings including dormitories, dining hall, computer room, and office. It shares cultural celebrations with the neighbouring community and is training its first football (soccer) team to compete with other local Thai school teams.

The current program for the fifty-seven students entails two years of studies in English, Thai, Community Health, computer use, accounting, human rights, leadership, and various other subject areas, depending on the talents of visiting teachers. The language of instruction for most subjects is Karen. The school has four paid Karen teachers. Of particular interest, Kaw Tha Blay's program includes an agriculture component. PUB purchased 3.5 acres of land close by and has also been loaned land by Thai Karen villagers on which it grows rice, vegetables, and fruit trees and raises animals that now feed the students. Along with studying, the students work the land. This holistic approach is rooted in a desire to develop skills, to be self-sustaining (at least in provision of food), and to foster commitment to the value of community. As in the case of Youth Connect, Kaw Tha Blay derives both physical security and potential for sustainability from the ties it has created with the neighbouring village and local authorities.

Last year, Kaw Tha Blay graduated twenty-two students. Although they lack the worldliness of students in Mae Sot, some have gone on to programs such as Min Ma Haw's post-ten program or to work for medical organizations providing services to the refugee community at Mae La or in Mae Sot. Others have returned to Karen state as teachers, medics, organizers, and leaders or in some instances, for better or worse, soldiers for the Karen military. An informal contract signed at the beginning of the program reminds students that their education is a gift in return for which they are expected to help their people. The Karen and Canadian project organizers work together to help them realize this goal.

While other post-ten programs are now being developed in the refugee camps along the border, this paper has deliberately focused on four operating in the urban (or in one case rural) refugee/illegal migrant context. ${ }^{6}$ While two (ACU and Min Ma Haw) are more academic and two (Kaw Tha Blay and Youth Connect) more vocational, each is guided by its own distinct philosophy and approach. As they are relatively new and have not been subjected to rigorous evaluation, it is difficult to assess students' satisfaction or to measure success. A close examination of outcomes is a reasonable next step in weighing the potential of these educational options. It is clear that presently they are too small and few to cope with the overwhelming needs of the displaced Burmese community. The large number of applicants to Min Ma Haw is only one indicator of the demand, and the numbers are growing. Burmese youth (education migrants or refugees, as one project organizer called them) cross the border unaccompanied in order to attend the migrant schools and post-ten programs because, however deficient these programs may be in funding, materials, or teachers, they are preferable to the restrictive and repressive education offered in Burma/Myanmar. Unfortunately 
the number of displaced Burmese students finding avenues for employment or for continuing education beyond these programs remains small. New developments are afoot. As the Thai Ministry of Education becomes increasingly interested in regulating the migrant "learning centres," it may also open a door to enrolment in vocational education to some Burmese youth. However, given other political uncertainties in Thailand, such a development is hardly assured.

What can the refugee advocacy and protection community learn from these educational initiatives? First, educators around the world have a special role to play in facilitating education of refugee youth in protracted situations. As volunteer teachers, they can fill gaps in educational programs developed by the refugee community by offering their time and expertise. All of the programs described above make some use of international volunteers. Educators are also in a position to facilitate development of distance education programs and educational partnerships. Second, flexibility and creativity in program development are imperative. As already noted, programs emerge and evolve based on changing needs and on the availability of trained teachers in different subject areas. Finding ways to work within limitations and to maximize opportunities that present themselves has been a necessary survival strategy for the Burmese educators. At this time, given the resources available, those who are developing new programs and partnerships must be prepared to work with this reality. However, educational institutions can help by providing incentives to teachers who are less likely to seek volunteer opportunities (i.e., science teachers) to undertake partnerships and by providing logistical and even financial support as in the case of ACU. All of these initiatives will succeed only if framed within a collaborative context that responds to the needs and aspirations of the displaced themselves.

Another valuable lesson, however, is the importance of genuine, larger collaboration between educators from abroad, educators in the displaced community (who are best situated to assess the needs of refugee youth) and, whenever possible, local authorities and educators in the host community-who cannot realistically be expected to embrace these initiatives unless they respect their communities' needs and are supported by the international community. Again, Youth Connect and Kaw Tha Blay provide excellent examples of respectful, friendly partnerships with the local Thai community-which can improve conditions for the migrant population generally.

Finally, all of these initiatives depend on civil society donors, not big-government aid agencies. Unfortunately, this kind of aid is unreliable. Donors run out of resources, or they lack trust in the accountability and transparency of project organizers. In order for these small projects to succeed, donors must understand their responsibility to the communities they are assisting, work with them as genuine partners, and be prepared to make longer-term commitments to them. At the same time, they must deepen understanding of the protracted refugee situation within their own donor communities. On the positive side, whatever the limitations of this kind of financing, it allows those developing programs to address problems and seek solutions with a degree of personal engagement, flexibility, and esprit de corps between partners that governments rarely if ever achieve. Governments should still be held responsible. The obligation to provide education is embedded in international law as reflected in Article 26 of the Universal Declaration of Human Rights, to which all members of the United Nations are party, as well as in Article 13 of the International Covenant on Economic, Social and Cultural Rights and Articles 28 and 29 of the Convention on the Rights of the Child. However, since fostering education is ultimately the responsibility of all (states and civil society) who embrace the ideals in these documents, advocates and educators should not wait for governments to deliver. The time is right and the opportunities abundant for everyone to strive together to meet the challenges posed by aspiring young refugee/migrant students such as those on the ThaiBurmese border.

\section{Notes}

1. Thailand has not ratified the 1951 United Nations Convention relating to the Status of Refugees and has its own definition of a refugee as someone who is fleeing fighting. The number of people in the nine camps in Thailand fluctuates. The Economist reported that "Border camps hold an estimated 150,000 Burmese, 10s of thousands of whom are unregistered"; see the article "Welcome Withdrawn," October 15, 2010, http://www.economist.com/blogs/ banyan/2010/10/burmese_refugees_thailand.

2. At the risk of alienating readers who are sensitive to the complex and problematic issue of ethnic difference in Burma/ Myanmar, for the sake of simplicity, the term "Burmese" is used inclusively in this article to refer to all nationals of the state of Myanmar (Burma) and their sometimes stateless children, including those belonging to ethnic minorities such as the Karen, the most populous of the Burmese ethnic groups in the Mae Sot area. In addition, both names for this country are used because while Myanmar is the official name (chosen by the ruling junta in the 1990s), Burma is the name preferred by most displaced Burmese. Finally, the number of Burmese migrants fluctuates. A report by Human Rights Watch estimates 1.8-2 million to 3 million migrants in Thailand, of whom 70 per cent to 80 per cent 
originate in Burma (Human Rights Watch, From the Tiger to the Crocodile, February 2010, 24).

3. According to Educational Provision for Stateless and Cross National Migrant Children in Thailand (Ministry of Education, Office of the Education Council, 2008, 17), Thailand as a whole has "some 88 migrant schools with an estimated 15,855 students and 981 teachers."

4. It is not impossible for Burmese students to obtain scholarships in other countries if they have a Burmese passport. However, restrictive immigration policies in many countries make it difficult for youth from refugee producing countries such as Burma/Myanmar to obtain the necessary visas.

5. The Thai Ministry of Education insists that Burmese informal schools registered with the MOE identify themselves officially as "learning centres" rather than as schools or colleges. Explanation of other recent developments with regard to regulation of the schools by the MOE would require a lengthier discussion than can be provided here.

6. For an excellent overview of educational challenges faced by youth in the refugee camps, see the report Living in Limbo: Burma's Youth in Thailand See Few Opportunities to
Use Education and Vocational Skills (Women's Commission for Refugee Women and Children, 2008).

Mary Purkey teaches humanities at Champlain College in Sherbrooke, Quebec, Canada, where she has co-coordinated the Bishop's University/Champlain College Refugee-Student Sponsorship Committee for the last nineteen years. She is also a founder and currently coordinator of the Eastern Townships-Mae Sot Education Project, a community-based project that has been sending small teams of youth volunteers from Quebec to assist in six informal schools for Burmese migrant and refugee children in Mae Sot, Thailand, since 2004. The project also provides limited funding to its partner schools. As co-chair (in 2008-10) and currently a member of the Steering Committee for the Overseas Protection and Sponsorship Working Group of the Canadian Council for Refugees, she has also been involved in refugee advocacy in Canada. 